\title{
Implementation Analysis of Corporate Social Responsibility (CSR) in Central Java in the Context of Natural Disaster Risk Areas
}

\author{
Agus Naryoso ${ }^{1 *}$, Sri Widowati Herieningsih ${ }^{1}$ \\ Department of Communication, Universitas Diponegoro Jl. Prof. H. Soedarto, S. H. Tembalang, \\ Kota Semarang, Jawa Tengah 50275, Indonesia
}

\begin{abstract}
The practice of Corporate Social Responsibility in Indonesia related to natural disaster has not been touched by the company, even though Indonesia is a country with big catastrophic category. This research tries to know the CSR commitment of Company in handling natural disaster. The research uses theory of CSR Implementation Model Pinkston and Carroll (1996) with research resource are head of companies of PT. Bank BNI, PT. Telkom, Regional Division of Central Java / DIY, PT. Pertamina, MOR Semarang and Sultan Agung Islamic Hospital Semarang. CSR implemented by BUMN is more on effort to perform social generosity in the form of providing basic needs for people affected by disaster, while Sultan Agung Islamic Hospital implements activities in the form of mass free medical for residents affected by tidal flood and annual flood around the hospital. Motives of BUMN such as PT. Pertamina, PT. Bank BNI and PT. Telkom, implement CSR activities are to obey the government's recommendation and obey legal aspects. CSR activities have not yet reached the conditions to empower affected communities to be self-sufficient in facing disaster situations.
\end{abstract}

Keywords: Natural Disaster; CSR Motive; Community Empowerment

\section{Introduction}

Corporate Social Responsibility (CSR) is a government policy to encourage corporate awareness of social problems. Corporate Social Responsibility Program is a regulation that is expected to overcome the main problems in society that can not be resolved properly by the government. The practice of CSR activities in Indonesia has not been well implemented by the company, the motivation for the implementation of CSR activities is only as a form of legal compliance and avoid government reprimands. Even execution of CSR activities are much done unexpectedly without planning. CSR practices in Indonesia are often undertaken without coordination with the target. CSR is mostly done in the form of social generosity, a consumptive nature and it does not support the value of sustainability target. The presence of companies in the community should provide positive benefits, respond to long term sustainable social issues, and be able to

\footnotetext{
* Corresponding author: agusnaryoso@ gmail.com
}

suppress the emergence of potential protests and social intervention to the existence of companies[1].

Various activities Company CSR-related disasters in Indonesia, lead more to the practice of philanthropy by providing post-disaster assistance. Indonesia as a third country needs better CSR practices to address national development, especially on the issue of natural disaster management. Reality shows that many companies have started to realize the importance of engaging in social responsibility activities but many have not implemented according to the principles of true CSR activities. Companies that conduct business activities in disaster risk countries should be able to recognize characteristics and needs of affected communities, to empower optimally so as to help the community out of the problem and conduct productive activities. Good CSR implementation literature considers Triple Bottom Line Approach that are society, environment and business. Business will grow and bring profit when it balanced with social awareness. Private sector integration in disaster 
management becomes a strategic opportunity for business promotion especially in developing countries, partnerships between government and private sector provide opportunities for a wide range of interests, the private sector can promote mitigation by providing incentives, partnerships through CSR activities can be used to improve networks, complement planning and appropriate strategic action that is synergy and solidarity between government, private sector, civil society, academia and international institutions[2].

CSR-related disaster in Indonesia is more philanthropic and responsive, research for planning and evaluation is minimal. So it is not enough to know the effectiveness of CSR for the community in the area affected or riskto disaster as well as the benefits received by the company's CSR perpetrators. Therefore, it is important to study CSR implemented by the company in the context of Indonesia as a disaster risk country. Corporate Social Responsibility is also known as the Company's awareness and commitment to the community in the form of sustainable social responsibility to help address social issues that are integrated into the company's business. The implementation policy of CSR activities is part of business strategy and compliance with legal aspects, ethical standards and international legal norms. Implementation of CSR activities based on system theory that CSR and Public Relations are part of management strategy[3].

According to Gulzhan Buldybayeva[4], the implementation model of CSR activities should refer to the following major elements:

1. Promise : CSR is the fulfillment of corporate promises about social concerns whose profits for the company are not tangible but the success is real

2. Proposisi CSR is a concrete form of business correlation with the company's commitment to keep the environment safe.

3. Evidence : CSR activities are evidence of a partnership between business and the environment

4. Result : CSR is objective evidence for enhancing business credibility

The current model of implementing of disaster CSR activities in developing countries, refers to Pinkston and Carroll (1996), Edmondson and Carroll (1999), and Burton et al[5] (it can be seen in Figure I).

Visher (2006) says that the emphasis of CSR practices in developing countries should ideally still focusing on economics, filatropis occupies the highest priority as a form of CSR activities, followed by consistent legal and ethical social responsibility. The implementation of Philanthropic-based CSR activities departs from the empirical fact that these activities directly provide benefits to improve living standards and wellbeing and improve their living conditions and the dependent nature of predominantly developing country people, while law-abiding aspects of awareness of CSR activities are fewer than developed countries.
CSR development is more than just philanthropy (social philantrophy), but CSR should emphasize community empowerment and development. CSR must satisfies the interests and expectations of stakeholders and sustainable business. CSR needs to be regulated and institutionalized in normal business practices, CSR needs to be integrated into business functions[7]. CSR is expected to have a positive impact through the creation of social responsibility activities on the environment, employees, communities that are part of stakeholders.

\section{Methodology}

The research titled Analysis of Implementation of Corporate Social Responsibility (CSR) in Indonesia in the Context of Disaster Risk Country used postpositivistic paradigm method with mixed method. In this study, researchers used Sequential Exploratory research design, which collects and analyzes qualitative data, then collects and analyzes quantitative data. In this study, researchers more emphasis on qualitative methods[8].

\section{Discussion}

The CSR Implementation Model is an overview of CSR planner and policy maker's attitudes related to important aspects of implementation of CSR activities. CSR does not only necessarily meet ambitions and desires of the company, but also should consider the main needs of the target.

CSR programs implemented by BUMN is basically one form or effort to maintain good relationships with stakeholders. Business can not be managed without the participation and support of other parties. The aids provided to the community of 1 st ring group is an attempt to anticipate the absence of businesses blocking, for example they are not allowed to transport raw materials across residential areas, even avoiding blocking. From some facts obtained most companies prefer to execute CSR activities with the theme of improving social economic status, while the issue of disaster is less worked as an interesting CSR material by the company. In Semarang there are only a few CSR activities with the theme of disaster, but actually there are many potential disasters that occur in this region that requires commitment and concern of many parties. One of the most major disasters and dominant in Semarang is tidal flood disaster. The floods have very high vulnerability impacts in society such as physical, social, cultural, economic and environmental demographics. Pinkston and Carroll (1996), Edmondson and Carroll (1999), and Burton et al. $(2000)^{5}$ divide CSR practices into five stages, obeying government policy obligations, legal aspects, social generosity, economic empowerment. In the case of natural disasters CSR is directed to activities relating to the obligation to meet government recommendations in the form of provision of basic needs when disaster occurs, while in other context CSR is more focused on economic empowerment of the community. CSR 
practices when referring to Gulzhan Buldybayeva $(2014)^{4}$ that the main element of PT Telkom Regional Division IV Central Java / DIY implements CSR activities emphasizes on Promise aspect that as a company, BNI should concern to local community, even though it has no economic value at all, while Sultan Agung Islamic Hospital of Semarang more on efforts to establish a good partnership with local environment which is expected to have an impact on sustainability of the business, PT. Pertamina (Persero) Semarang MOR implement CSR activities carrying elements of evidence which emphasizes that CSR activity is evidence of a partnership between business and the environment

\section{Conclusion}

CSR practices by companies in Indonesia has not been targeting the CSR activities in the field of disaster, but more dominant in the effort of conducting economic empowerment. Research activities are carried out in almost every CSR activities planning but the research does not answer the substance of needs fulfillment of the target. Companies in Semarang have not responded to the needs of local communities regarding the handling of disasters that are executed in CSR programs, whereas Semarang has a high vulnerability to disasters such as flood, tidal flood, soil erosion and drought. Pertamina implements CSR activities in the form of planting. Sultan Agung Islamic Hospital (RSISA) implements CSR in the form of health services, it is in line with the hospital business where the activity is performed on the community around the area or Kaligawe region which the area is in category of high tidal flood disaster.

\section{References}

1. G. Hilson, An overview of land use conflicts in mining communities. Land Use Policy, Vol. 19, p. 65- 73 (2002).

2. T. S. Pinkston, \& Carroll, A. B. A, Retrospective Examination of CSR Orientations: Have They Changed?, J. Bus. Eth. , 15[2], p. 199-206 (1996).

3. J. Twigg, Corporate Social Responsibility And Disaster Reduction: A Global Overview, Funded by the UK Department for International Development (DFID): ESCOR award no. R7893, DFID supports policies, programmes and projects to promote international development, DFID provided funds for this study as part of that objective but the views and opinions expressed are those of the author alone, (2001).

4. G. Buldybayeva, Both Sides of CSR Practice: A Case from Oil and Gas Industry in Kazakhstan, Acta Polytechnica Hungarica, Vol. 11, No. 2 (2014).

5. L. V. Bertalanffy, General System Theory Foundations, Development, Applications, George Braziller, New York (1968).

6. C. A. Visher, Effective Reentry Programs, Criminology and Public Policy, (2006)

7. A.A. Hamidu, H. Md. Haron, and A. Amran, Corporate Social Responsibility: A Review on Definitions, Core Characteristics and Theoretical Perspectives, Vol 6 No 4 (2015).

8. T. A. Sirnayatin, Membangun Karakter Bangsa Melalui Pembelajaran Sejarah, Bandung: Universitas Pendidikan Indonesia (2013). 